\title{
The Public Character of the Resurrection
}

\author{
M. Douglas Meeks \\ Wesley Theological Seminary, Washington, D.C.
}

"If Christ has not been raised, then our preaching is in vain and our faith is in vain" (1 Cor. 15:14). Paul is right in this bold claim, but since the beginning of modern liberal theology it has been difficult to maintain its truth. With Schleiermacher the resurrection became an addendum, almost an afterthought, seemingly nonessential to the faith. Under this assumption the sermon on Easter Sunday can easily become a fumbling exercise in banality. In actuality, however, Easter is constitutive of our faith in what God has done, is doing, and will do in Jesus Christ. The Easter sermon and worship is an expression of what makes possible all acts of proclamation and worship, indeed the whole of Christian life.

Losing our trust in the resurrection is the deepest theological reason for the church's loss of its public character in our time. The loss of trust in God's resurrection power accompanies the rise of the liberal partition of life into the public and the private and the church's general surrender of the public sphere to management by the political, economic, and social sciences and technologies. The church has settled for the private spheres of life, the questions of meaning and value in individual and family life. It tends to help people cope with life as it happens to them within the public laws of property, work, and legitimate violence but fails to announce the new thing God intends to do in the public sphere of life. Thus whenever trust in the resurrection is absent or weak, the church's missionary presence in the world is correspondingly weak.

The church's difficulty in making a public witness is in large part its difficulty in bringing the logic of the resurrection into contention with other reigning logics in our world. The crucifixion of Jesus was public. But what actually happened between Good Friday afternoon and Easter morning is not a public event, knowable and provable historically. Without the resurrection, however, the cross and life of Jesus are not sufficient grounds for Christian faith. Without assurance in the public significance of the resurrection the church fails to appear publicly and, in the end, has no new word for the world.

We can speak of three dimensions in our public life, among others, in which the logic of the resurrection should be set over against prevailing logics. In the political dimension the logic of deterrence is still pervasive if not universal in the world's politics. In the final analysis, it is claimed, power struggles have to be determined by the threat or use of violence. But violence never creates the conditions of justice on which the peaceful relationships of power can flourish. Violence leads to further isolation, despondence, and regret, that is, the conditions of death.

In the economic sphere the rules of market exchange are the most universally spread logic in our world, which in and of itself is not bad. But in our society, as well as societies throughout the world, the laws which are meant to 
govern the distribution of commodities are increasingly determining the distribution of all social goods that persons and communities need for life and life abundant, such as, the distribution of healing, learning, the justice of courts, belonging, welfare and security, dignity, and even grace. ${ }^{1}$ When all things and relationships are reduced to commodities, the power of gifting, without which there can be no life, is destroyed. This engenders the conditions of death.

In the technological dimension the logic of the utility of nature has become second nature for all advanced peoples. Nature is reduced to the lifeless stuff which exists merely for the production of our "counter-creation." Our domination of nature means that nature has no dignity in itself, no right to life and future. Following from this like night from day is the destruction of our own life environment and, indeed, the denigration of our own embodied existence, that is, the conditions of death.

As prevailing public logics deterrence, commodity exchange, and utility of nature promise life, control, and future and are, as such, the stuff of progress. But they produce death-serving systems. They give structure to a human and natural economy in which large parts of humanity and nature are systemically excluded from the conditions of life. ${ }^{2}$ In the end they also destroy the humanity of those who are "in" the economy.

What about the resurrection gives it its public significance? What is the peculiar logic given in the resurrection which makes it the key to the public reality of the church? The resurrection is the economy of life. It is not merely a past event accomplished once for all; it is rather a process, a history which embraces the entire creation and in which all of humanity and nature will become the new creation. ${ }^{3}$ The resurrection points to the logic (logos) and power by which God will make all reality into a home in which all of God's creatures have access to life and life abundant. The church through the power of the Holy Spirit is meant to be a foretaste of this new creation already under the conditions of history. The church is God's resurrection household in which logics other than deterrence, commodity exchange, and utility of nature are to gain a real public toehold in history.

Regaining the public significance of the resurrection means at one and the same time regaining the historical significance of God's righteousness. To say resurrection is to speak of the whole history of God's righteousness in its past, future, and present form. The resurrection happened to Jesus, the resurrection will happen for the future of the whole of the creation, and the resurrection is happening now for the redemption of the history governed by death.

The resurrection, then, in the first sense is an eschatological act of God that happened to Jesus. It is Jesus, the humiliated, crucified one, who was raised by Abba through the power of the Spirit. The self-identification of the risen Jesus, "it is I," is at the heart of the resurrection. The crucifixion was the "last word" of the pax Romana, the great power of peace through deterrence. Jesus did not live by the household rules of the Greco-Roman oikonomia. His conviction according to the court of Caesar was: "This man is not just; he does not deserve to live." According to the logics of deterrence, commodity exchange, and utility of nature this one does not deserve a future, much less lordship over the future. The law of the power over human beings and nature 
gained a decisive public victory in the crucifixion.

The resurrection is God's verdict that this very same person is the righteous one. $\mathrm{He}$ is the one who deserves to live, for in him the righteousness which will shape the future of reality has taken shape. The new logos which takes shape in his life is the law of life, the law of grace. And to find the contour of this law the resurrection points us back to Jesus and his mission to build the new household of Israel. Because God's righteousness was beginning to reign Jesus' mission was a home-making movement. He announced the good news publicly to the homeless: "Come home!" The one who was raised is the one who made home with those who were systemically excluded from the household of Israel and the Greco-Roman household. Power is not the power of peace through the threat of violence but the peace of gifting and sharing, the peace of creating commons, of giving access to those who had been defined in such a way that they had no access to the conditions of life. The resurrected one is the one who gave name and story to the nameless and historyless, bread and table to the hungry, power to stand to those who were bent over, confrontation to the listless sinner, and a towel to those who had received no call, even though they be poor, to serve God's poor. If the resurrection happened to this one, then power, law, and justice take on a qualitatively different life in public.

But the resurrection did not happen only to Jesus or only for the believer in Jesus. The resurrection is not a private act performed on Jesus or an esoteric truth for Christians alone. The resurrection happened for the whole creation. When the primitive church chose the apocalyptic word "resurrection" to describe what happened to Jesus they meant the future of God's utter defeat of death and its logics in the whole of reality. They meant that in the resurrection the power of death which drives history has been annihilated in Jesus and that the destruction of death in all things has been promised by God in Jesus' resurrection. The resurrection is not complete until the general resurrection of human beings and nature when God will remember what has been violated and torn apart by the arrogance of deterrence and the laws of exclusion. The resurrection gives our life a horizon. It turns us toward the future in which God's righteousness, God's power for life, will reign in all of reality.

The resurrection is also happening in the present. In fact, that the resurrection power is at work in the present is the presupposition of the church. The risen Jesus is present and at work through the power of the Holy Spirit. In the midst of violence, unjust exchange, and extraction the time of the reign of God's power of resurrection is beginning. The resurrection is not hidden. We are, to be sure, waiting for the ultimate parousia of Jesus. But parousia means not only a coming presence but also a present coming. The whole reason for the existence of the church is to show forth public signs of the presence of the living crucified one. The resurrection is for all creatures, but the resurrection house building begins with those who are subjected to the terror of violence, hunger, and exploitation. If the resurrected crucified one is present, it is time for the church to engage in resurrection praxis.

In order to speak more concretely of a public resurrection praxis we should look more closely at the meaning of God's righteousness which is the power of resurrection. Righteousness in the biblical traditions is not first of all a moral 
or anthropological term. It means in almost every case God's power for life against death. In that sense righteousness is the key term of the scriptures. If we say that God's righteousness is at the heart of the resurrection, we mean, therefore, that the first question of the resurrection is not whether and how we shall live beyond death but rather whether God is Lord of death and whether this can be shown publicly. For if that question is not settled, it is no use for us to turn to any other theological question. The resurrection of God's act by which God shows Godself the victor over death in Jesus Christ and promises God's victory over death in all things. The resurrection is the absolute beginning and ground of Christian life and theology.

God's righteousness is at work in the three primary redemptive events of the biblical traditions, namely, the exodus, the original creation, and the resurrection. These events begin paradigmatically with the exodus narrative: "Once we were slaves," but with a mighty, outstretched arm Yahweh brought us out of the living death of Pharaoh's economy into a new household of freedom (Deut. 6). It is clear from the beginning that God's righteousness is creative justice, that is, the power to call life out of the conditions of death.

The creation narratives follow the same logic of righteousness as they portray the God of the exodus bringing all things into being out of the power of nothingness, the power of death. As in the exodus, through God's word of righteousness God calls all things that are out of the grasp of chaos and nothingness to life.

So it is in the resurrection. Abba and the "the Spirit of righteousness" go to the deadly dangerous regions of death to bring back the dead member of the community. Righteousness is the power to suffer death and to create life against death. The God who calls into being the things that are not (1 Cor. 1), who makes the dead live, is also the one who makes the godless just. God is not the quintessence of power or law. God is the power that quickens into life, that makes the poor rich, that lifts up the humble and raises the dead.

Righteousness in the primitive biblical sense can mean poetically to "stand with one's chin up." It means no longer to have one's face ground into the dust; no longer to have to bow down to the tyrants and the executioners; no longer to have to live by the threatening rules of the lex talionis or the incalculable ways in which the strong can control exchange relationships to the detriment of the weak. Righteousness means to stand by means of the gift of power from God.

One of the New Testament words for resurrection is anastasis. It suggests a play on words with important theological implications. Anastasis means to "stand up," no longer bound by death and its laws. "Stasis" means to "make a stand" or to "revolt." We have the same word play in English: resurrection and insurrection. Jesus was not only raised by God but also had to get up, to arise. He had not only to receive God's righteousness but also to awaken and to live and make a stand with God's righteousness. Being raised from the dead as the "first fruits of those who have fallen asleep" (1 Cor. 15:20), he arose to work against the power of death.

So it is with us. The resurrection creates a "standing up" household. We are quickened by God's power for life. But having the power no longer to be 
bowed down by the law of death means that we take a stand against all forms of death in our environs.

The first sign of the raised and arising household of resurrection is rejoicing. The Christian faith begins with the Easter laughter and dancing or it has not begun at all. Or, another way to say this is that the Christian faith becomes public when it testifies to the world that the law of death is not the world's fate. The world has always perked up its ears when, in spite of the fact that the world is so clearly going to hell, the church has steadfastly rejoiced through resurrection song and dance. Despite its frantic manufacturing of happiness the world expects from every quarter a counsel of doom, an apocalyptic announcement of the last judgment. The primary possibility of testimony to the world is the church's own public celebration of God's power over death. Not much else in the Christian life will be plausible without this. When the church is not publicly engaged in celebration even in the face of evil and death, it has no chance to make a difference in the world. The world, in the final analysis, provides no reason for such a "feast without end." The reason for such a public celebrative mode of life is given in the words of the father of the prodigal son, "This my son was dead, and is alive" (Luke 15:32). This leads to Paul's emphatic enjoiner of the public life of the resurrection household, "Rejoice in the Lord always; again I say, Rejoice" (Phil. 4:4). This rejoicing belongs to the peculiar militancy of the ecclesia militans, the strange way in which God intends that the resurrection household work publicly against the power of death in all its forms.

One reason we have lost the public sense of the resurrection is that we have lost the public sense of death. The resurrection prevents all spiritualization of death. When we connect death with the cessation of the cardiopulmonary or brain systems, we have not even begun to fathom the cosmic reach of death. Death is the power of nothingness which intrudes wherever life makes a showing. Death has a thousand forms by which it attempts to make life vain, void, hopeless, and without future. Death works by cutting off the future and isolating people from each other and from nature. When a mother or father loses his or her job and has no way to feed his or her children, death is at work and soon performs its ugly destruction on the family and soon cuts off the generation of the generations. When one person glances at another with the intention "I do not love you, care for you, or hope for you," death is at work, for death thrives on isolation and the growing cold of love. When one nation decides it has the right to use its might to determine the future of another, death has a field day, even if the martial acts be called just, for the seeds of remorse and recrimination are planted so deep that the justice which creates peace needs ever more heroic acts of nurture. When human beings trample on nature as if the ecosphere did not need its own breathing space or did not have its own rights to home, death wins the day, for it applauds its own easy victories when one part of creation considers another part already lifeless. Death is universally and multifariously potent. It does not help when we imagine it controlled by our artifices. The public significance of the resurrection is that only God is powerful against death and that only with a public practice of God's gift of resurrection power can we make any public stand against death and its laws. 
By creating trust in the victory of God's righteousness at the end of history, the resurrection gives the household of Jesus Christ a thirst for righteousness in the present.

If we turn now to the public praxis of the hope and power of resurrection, we can begin by observing that the resurrection means mission. In the original apostolate only those who believed in the resurrection were sent into mission and only those who were sent into mission believed in the resurrection. To speak of the public significance of the resurrection, then, means to speak of the ways in which the resurrection makes it possible for persons and communities to engage publicly in the gospel's mission of life in a necrophilic world. In what ways does the power of resurrection defeat our death-dealing ways of dealing with death?

The ways we deal with death keep us from being public missionaries of Christ: we repress death, we say that it is only "natural," we create beliefs and systems of immortality, we divide ourselves up into soul and body in order to try to make ourselves safe from death, and we isolate ourselves from human beings and those aspects of nature that we do not consider beneficiaries of our way of negating death. All of these ways of dealing with death end up serving death in not only the psychical aspects of our being but above all in our public life. They all lead eventually to violent exclusion of some from the household of life and to the collapse of the household itself.

Ernest Becker has shown that most of our waking hours are spent trying to secure ourselves against death by manufacturing some system of immortality. ${ }^{4}$ We treat many of our political and economic systems as if they were impenetrable by death and thus capable of protecting us from death. Our denial of death is publicly deadly. Our urge to maintain systems with which we identify our power against death leads us to death-serving political and economic decisions. It leads us also to the myopic tendency to identify the threat of death with our enemy so that we end up using a universally destructive force, that is, a force that destroys us as well. The liberation of the gospel of the crucified risen one is that we are freed from having to create our own immortality. This gives us energy and time for public work for the conditions of justice, the true way to serve God's power over death.

A widespread cultural attempt to deal with death is to deny its deadliness or to claim that it is only "natural." This requires that we religiously numb ourselves to the pain of death. The result is that we lose the passion for life. The more we repress the reality of death, the less we are able to love life. Repressing death makes us increasingly private, hidden, introverted people unable to take responsibility for life in the public world, unprotected as it is from death. The denial or diminishment of the reality of death makes us apathetic creatures, incapable of staying in love with persons, animals, and the inanimate parts of nature, subject to the frailty of flesh as they are. Only God's power of resurrection can reconcile life and death in our living so that we can engage publicly in acts of love against the conditions of death.

Another deadly attempt to deal with death is to divide our being into soul and body and to cede the body to the sphere of death while elevating the soul beyond the reach of death. In all societies where this has played itself out in 
public there have appeared slavery, racism, pornography, sexism, and the repression of the disabled. The denigration of the body in order to protect oneself from death led the Christian plantation owners to affirm the eternal life of the slave's soul while claiming the right to do whatever they would to the slave's body. Pornography assumes that the body may be used and commodified without ruination to the person. Advances in medical technology make it ever more difficult to integrate one's being once the body becomes the sole object of medical procedures. Our economy more and more measures the fiscal flows and accumulation of wealth without the slightest reference to embodied human beings who must this day have access to bread and the other means by which they can survive the day. The Christian expectation of life beyond death is the resurrection of the body. This has everything to do with how we live today and has immense implications for public life. If we are embodied spirits or inspirited bodies, then our political, economic, and ecological life must consistently recognize this.

Faith in the resurrection is a living power which frees us from the illusions of the threat of violence, possession, and the humiliation of nature and body. It raises us in the present, rejoicing, so that we can make a public stand against the conditions of death and through the power of love serve God's justice in the world.

\section{NOTES}

${ }^{1}$ See Michael Walzer, Spheres of Justice: A Defense of Pluralism and Equality (New York: Basic Books, 1983).

${ }^{2}$ M. Douglas Meeks, God the Economist: The Doctrine of God and Political Economy (Minneapolis: Fortress Press, 1989).

${ }^{3}$ Cf. Jürgen Moltmann, The Way of Jesus Christ: Christology in Messianic Dimensions, trans. Margret Kohl (San Francisco; Harper, 1990), 240-45.

4 Ernest Becker, The Denial of Death (New York: The Free Press, 1973). 


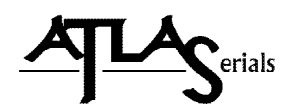

Copyright and Use:

As an ATLAS user, you may print, download, or send articles for individual use according to fair use as defined by U.S. and international copyright law and as otherwise authorized under your respective ATLAS subscriber agreement.

No content may be copied or emailed to multiple sites or publicly posted without the copyright holder(s)' express written permission. Any use, decompiling, reproduction, or distribution of this journal in excess of fair use provisions may be a violation of copyright law.

This journal is made available to you through the ATLAS collection with permission from the copyright holder(s). The copyright holder for an entire issue of a journal typically is the journal owner, who also may own the copyright in each article. However, for certain articles, the author of the article may maintain the copyright in the article. Please contact the copyright holder(s) to request permission to use an article or specific work for any use not covered by the fair use provisions of the copyright laws or covered by your respective ATLAS subscriber agreement. For information regarding the copyright holder(s), please refer to the copyright information in the journal, if available, or contact ATLA to request contact information for the copyright holder(s).

About ATLAS:

The ATLA Serials (ATLAS $®)$ collection contains electronic versions of previously published religion and theology journals reproduced with permission. The ATLAS collection is owned and managed by the American Theological Library Association (ATLA) and received initial funding from Lilly Endowment Inc.

The design and final form of this electronic document is the property of the American Theological Library Association. 